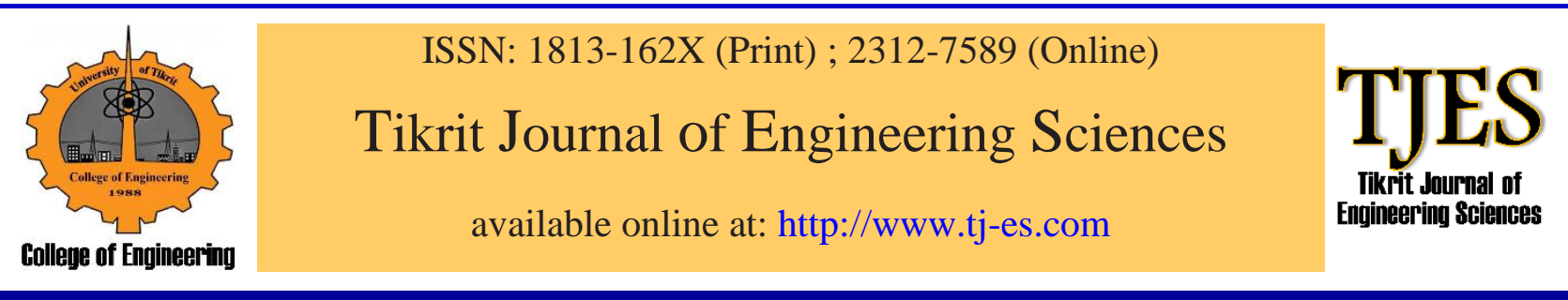

\title{
Increasing $\mathrm{NaCl}$ Concentration by using Precipitation and Filtration Process at Optimum Temperature
}

\author{
Oil \&Minerals Engineering College \\ Tikrit University \\ Salahuddin \\ Iraq
}

\section{Keywords:}

$\mathrm{NaCl}$ salt precipitation filtration optimum temperature

\section{A R T I C L E I N F O}

\section{Article history:}

Received $\quad 05$ September 2016

Accepted 12 July 2017

Available online 30 September 2017

\section{A B S T R A C T}

The sodium chloride salt or (food salt) is commonly used for consumption in our homes, as well as a raw material in industries and laboratories. The quality of this salt mainly depends on the sodium chloride concentration. The aim of this research is to obtain an optimum condition in production of $\mathrm{NaCl}$ industrial salt by using sedimentation and filtration process in order to achieve high concentration of industrial salt. The research has been conducted in two parts, mathematical calculations by mathematical models and experiment process by mixing the stearic acid with $\mathrm{NaOH}$ solution to produce the sodium stearic and the solution has been mixed with sea water, then the white solid was emerged, there are a calcium stearic and magnesium stearic. The final step is the filtration of evaporated mixture to obtain the intended salt concentration. Results obtained indicate that both result data are approximately identical with small deviation. The maximum concentration obtained of $\mathrm{NaCl}$ is $95 \%$ at optimum temperature of $83{ }^{\circ} \mathrm{C}$.

(c) 2017 TJES, College of Engineering, Tikrit University DOI: http://dx.doi.org/10.25130/tjes.24.3.12

زيادة تركيز كلوريد الصوديوم باستخدام عملية الترسيب والترشيح في درجة الحرارة المثلى

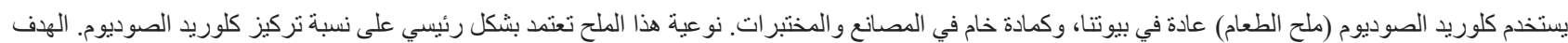

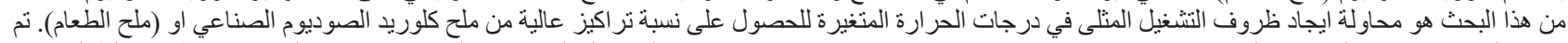

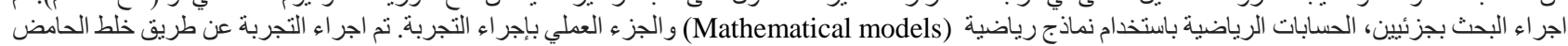

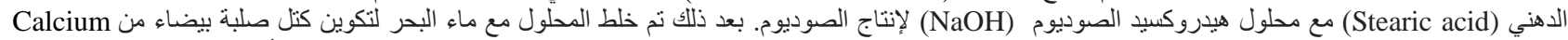

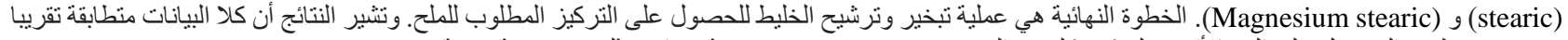

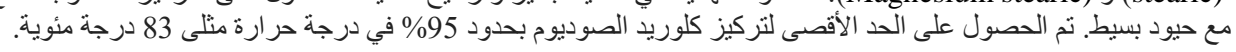

\section{INTRODUCTION}

One of the most kitchen cabinet items used for many purpose in our homes is the food salt. Common salt is a mineral that composed of sodium chloride $(\mathrm{NaCl})$, a chemical compound belong to the class of salts. salt in its natural form as a crystalline mineral known as rock salt. Salt is present in seawater [1]. Salt is essential for human life, and saltiness is one of the basic human tastes. The tissues of animals contain large amounts of salt [2]. Salt is produced from salt mines or by the evaporation of seawater. Its main industrial products are caustic soda and chlorine and is used in many fabrication processes including the manufactures of some industrial products such as polyvinyl chloride, drugs and plastics [3].

The global need for $\mathrm{NaCl}$ salt in 2015 is about 3.6 million tons per year consisting of consumed salt of about 1.2 million tons and industrial salt of about 2,400,000 tons .Needs for $\mathrm{NaCl}$ salt is expected to increase in line with the huge development of population and industrial growth, so there is a need for increasing the concentration of $\mathrm{NaCl}$ in salt [4].

Some researches intended to reduce the impurities in the salt by combination laundering and rapid dissolution. This study was reacting $\mathrm{NaCl}$ salt with $\mathrm{Na} 2 \mathrm{CO}_{3}$ and $\mathrm{NaOH}$, so arising precipitate of $\mathrm{CaCO}_{3}$ and $\mathrm{Mg}(\mathrm{OH})_{2}$. 
A study performed some experim-ents to determine the optimum ratio of $\mathrm{Ca} / \mathrm{Mg}$ either with or without flocculants. The results obtained shows that the refining salt is very influenced by the ratio $\mathrm{Ca} / \mathrm{Mg}$, whereas if the ratio is too large or too small then the result with impurity is not good. Additions flocculent enough to affect a decrease in levels of $\mathrm{Ca}^{+2}$ and relatively little influence decreased levels of $\mathrm{mg}^{+2}$ [5]. Production the salt performed using solvent evaporation with $\mathrm{NaOH}$ and $\mathrm{CO}_{2}$ gas, Solvent $\mathrm{NaOH}$ and $\mathrm{CO}_{2}$ is a function used for precipitate of the $\mathrm{Mg}^{+2}$ and $\mathrm{Ca}^{+2}$ ions [6].

A study conducted on manufacturing industrial salt from seawater by three methods, namely the addition of stearic acid, addition of sodium carbonate and modifications process (modification of process is incorporation deposition method). Results obtained from this study show that the process modification method gives good results [7].

\section{METHODOLOGY}

Research has been conducted in the following steps:

- Mathematical calculations by two models for:

1. Reducing levels of $\mathrm{Ca}^{+2}$ and $\mathrm{Mg}^{+2}$.

2. Increasing the $\mathrm{NaCl}$ salt.

- Experimental process had been conducted to product the:

1. $\mathrm{Ca}^{+2}$ and $\mathrm{Mg}^{+2}$ stearate.

2. $\mathrm{NaCl}$ salt.

- Comparison the calculation and experimental results to prove the validation of the models used.

-The experiment was conducted with a fixed variable in the processing time of 60 minutes; the volume of seawater is two liters and a mole ratio of stearic acid with sodium hydroxide 1:1. The experimental design used is the central composite design will be according to data results from Eqs. (1) and (2) as shown in Table 1.

Table 1

Experimental design data.

\begin{tabular}{llll}
\hline $\mathbf{B}_{1}$ & $\mathbf{B}_{\mathbf{2}}$ & $\begin{array}{l}\text { Temp. } \\
\left({ }^{\circ} \mathbf{C}\right)\end{array}$ & $\begin{array}{l}\text { Concentration } \\
\text { Na Stearate }(\%)\end{array}$ \\
\hline 0.000 & -1.414 & 83.00 & 5.000 \\
1.000 & -1.000 & 80.00 & 10.00 \\
1.000 & 1.000 & 90.00 & 10.00 \\
0.000 & 0.000 & 83.00 & 7.500 \\
-1.000 & 1.000 & 80.00 & 10.00 \\
0.000 & 0.000 & 85.00 & 7.500 \\
-1.000 & -1.000 & 85.00 & 3.960 \\
-1.414 & 0.000 & 85.00 & 11.04 \\
0.000 & 1.414 & 77.93 & 7.500 \\
1.414 & 0.000 & 92.07 & 7.500 \\
\hline
\end{tabular}

\subsection{Mathematical Calculations}

We will use $B_{1}$ and $B_{2}$ as coding for the variables of temperature and concentration of sodium stearate. The $B_{1}$ and $B_{2}$ relationship with variable temperature and the concentration of sodium stearate as presented in Eqs. (1) and (2) [8].

$B_{1}=\frac{T-83^{\circ} \mathrm{C}}{5^{\circ} \mathrm{C}}$
$B_{2}=\frac{T-7.3^{\circ} \mathrm{C}}{2.4^{\circ} \mathrm{C}}$

where:

$B_{1}$ : Temperature variable.

$B_{2}$ : Concentration of sodium stearate.

$T$ : Temperature.

\subsection{Experiment Process}

The seawater is used as the main raw material for producing the salt, stearic acid and sodium hydroxide are obtained from the chemical store. The reactor used in the form of stirred tank equipped with a heater and a temperature controller. Process and apparatus are presented in Fig. 1.

Experiment was conducted on the following stages:

- The manufacture of sodium stearate,

- The reaction process, and

- The screening process and the formation of salt crystals.

Sodium stearate made by mixing stearic acid and water. The seawater is first filtered, heated, and vaporized water. The seawater is then treated with a solution of sodium stearate at predetermined operating variables. The reaction carried out in a stirred reactor equip-ed with temperature regulator. The solids that formed was filtered to separate the filtrate with sediment. The resulting filtrate was analyzed to determine the levels of $\mathrm{Ca}^{+2}$ and $\mathrm{Mg}^{+2}$, and then the water is evaporated to obtain the salt deposits for its $\mathrm{NaCl}$ content was analyzed.

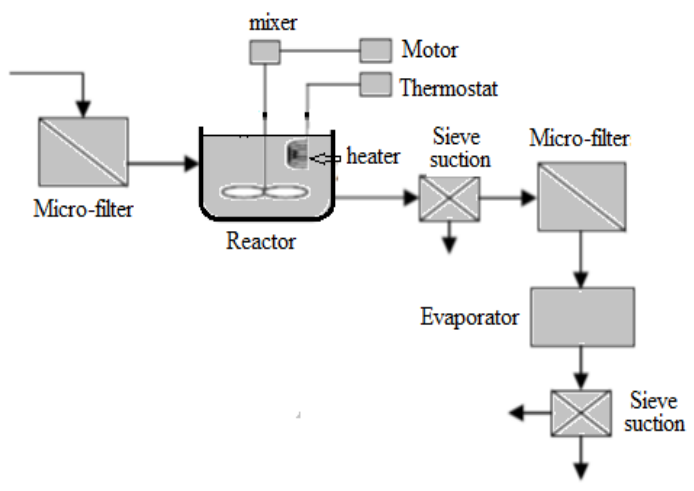

Fig. 1. The experimental setup.

\section{RESULTS AND DISCUSSION}

The maximum concentration obtained of $\mathrm{NaCl}$ is $95 \%$ at optimum temperature of $83^{\circ} \mathrm{C}$. Fig. 4 shows that the point to point of the experiment is still out of the point of maximum reduction that can be achieved. From Fig. 4 we can be concluding that $B_{2}$ on the value of 2.663. The value lies outside of the operating variables to $B_{2}\left(-1.42 \leq B_{2} \leq\right.$ 1.42). we can be concluding that $B_{2}$ on the value of 2.663 . The value lies outside of the operating variables to $B_{2}$ ($1.42 \leq B_{2} \leq 1.42$ ).

\subsection{Optimization Process in the Reduction Average of $\mathrm{Ca}^{+2}$ and $\mathrm{Mg}^{+2}$ lons}

$\mathrm{Ca}^{+2}$ and $\mathrm{Mg}^{+2}$ ions is the largest impurities contained in seawater. The existence of these two kinds of ions, causing salt products have low levels of $\mathrm{NaCl}$. In present 
work, the $\mathrm{Mg}^{+2}$ and $\mathrm{Ca}^{+2}$ in seawater will be deposited into $\mathrm{Mg}$-Ca-stearate and stearic using Na-stearate. According to the model in Eq. (3) [8].

$$
\begin{aligned}
Y= & 94.41+1.087 B_{1}+0.2 B_{1}{ }^{2}+1.1 B_{2}- \\
& 0.24 B_{2}{ }^{2}-0.34 B_{1} B_{2}
\end{aligned}
$$

Results of reduced levels of $\mathrm{Ca}^{+2}$ and $\mathrm{Mg}^{+2}$ is shown in Table 2 where (Y) is the average of reduction $\mathrm{Mg}^{+2}$ and $\mathrm{Ca}^{+2}$ ions. The first column and the second is the operating conditions used in the experiment. The fifth column is the conversion average of $\mathrm{Mg}^{+2}$ and $\mathrm{Ca}^{+2}$. The sixth column is

Table 2

Results of reduced levels of $\mathrm{Ca}^{+2}$ and $\mathrm{Mg}^{+2}$ ions. the result of the calculation of the average conversion of $\mathrm{Mg}^{+2}$ and $\mathrm{Ca}^{+2}$.

By sing the model of Eq. (3), the obtained reduction average of $\mathrm{Ca}^{+2}$ and $\mathrm{Mg}^{+2}$ is in range of about (89-91\%). Results obtained in this experiment is less than the intended reduction average $94 \%$ because the lack of reactants sodium stearate reacting with $\mathrm{Ca}^{+2}$ and $\mathrm{Mg}^{+2}$. The value of critical variable $B_{1}$ is -0.517 at a temperature of $82^{\circ} \mathrm{C}$ and $B_{2}$ is about 2.663 for the concentration of sodium stearate of $13 \%$. Comparison between calculated and experimental results on reduction of $\mathrm{Mg}^{+2}$ and $\mathrm{Ca}^{+2}$ is shown in Fig. 2 and reduction average of $\mathrm{Mg}^{+2}$ and $\mathrm{Ca}^{+2}$ is

\begin{tabular}{|c|c|c|c|c|c|}
\hline $\mathbf{B}_{1}$ & $\mathbf{B}_{2}$ & $\begin{array}{l}\text { Conversion of } \\
\mathrm{Mg}^{+2}\end{array}$ & $\begin{array}{l}\text { Conversion of } \\
\mathrm{Ca}^{+2}\end{array}$ & $\begin{array}{l}\text { Conversion average } \\
\left(\mathrm{Ca}^{+2} \& \mathrm{Mg}^{+2}\right)\end{array}$ & $\begin{array}{l}\text { Calculated } \\
\text { results\%, }(Y)\end{array}$ \\
\hline 0.00 & -1.50 & 97.89 & 83.45 & 90.12 & 92.22 \\
\hline 1.00 & -1.00 & 97.98 & 87.39 & 92.69 & 94.69 \\
\hline 1.00 & 1.00 & 99.04 & 89.72 & 94.41 & 96.21 \\
\hline 0.00 & 0.00 & 99.31 & 86.31 & 92.83 & 94.41 \\
\hline-1.00 & 1.00 & 99.75 & 84.64 & 92.20 & 94.72 \\
\hline 0.00 & 0.00 & 99.00 & 88.76 & 93.85 & 94.41 \\
\hline-1.00 & 0.00 & 99.13 & 81.23 & 90.13 & 93.52 \\
\hline-1.41 & 0.00 & 99.18 & 87.34 & 93.29 & 93.27 \\
\hline 0.00 & 1.41 & 99.30 & 91.86 & 95.58 & 95.48 \\
\hline 1.41 & 0.00 & 99.06 & 91.82 & 95.44 & 96.34 \\
\hline
\end{tabular}
shown in Fig. 3.

\subsection{Optimization Process in the $\mathrm{NaCl}$ Concentration}

The optimization process is also observed in the $\mathrm{NaCl}$ concentration of the salt formed by using a mathematical model in Eq. (4) [8].

$$
\begin{gathered}
Y=93.41-0.35 B_{1}-0.34 B_{1}{ }^{2}+3 B_{2}-0.94 B_{2}{ }^{2} \\
-2 B_{1} B_{2}
\end{gathered}
$$

Results of Calculation results of $\mathrm{NaCl}$ salt concentration $(\%)$ or $(Y)$ are shown in Table 3 where $(Y)$ is the average concentration (\%) of $\mathrm{NaCl}$ salt. The third column is the result of analysis of $\mathrm{NaCl}$ concentration on salt products and the fourth column is the result calculation of concentration of $\mathrm{NaCl}$. Comparison between calculated and experimental results on production of $\mathrm{NaCl}$ salt is shown in Fig. 4, while Fig. 5 represents the graph of production of $\mathrm{NaCl}$ salt.

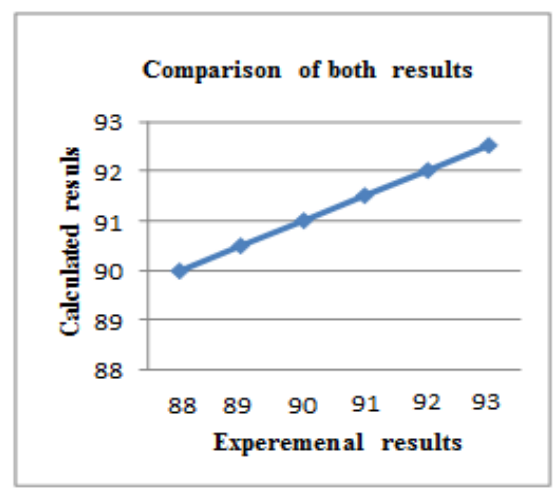

Fig. 2. Comparison between calculated and experimental results on reduction of $\mathrm{Mg}^{+2}$ and $\mathrm{Ca}^{+2}$.

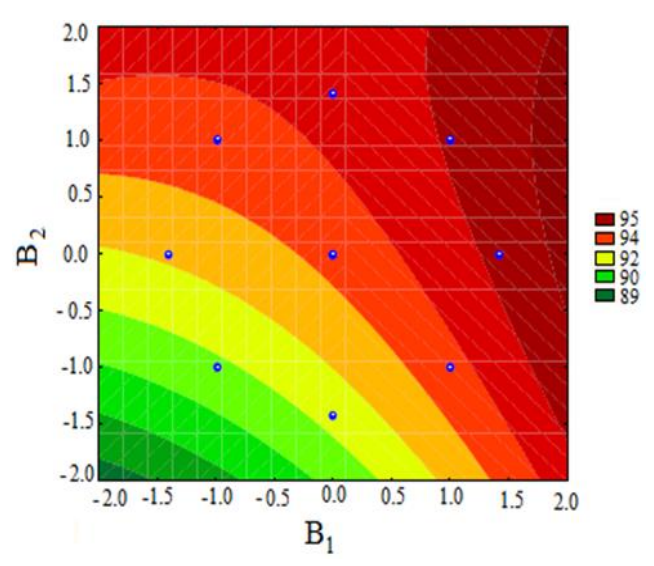

Fig. 3. Two-dimensional graph of the reduction average of $\mathrm{Mg}^{+2}$ and $\mathrm{Ca}^{+2}$.

Table 3

Results of calculation results of $\mathrm{NaCl}$ concentration (\%) in salt products.

\begin{tabular}{lcll}
\hline $\mathbf{B}_{\mathbf{1}}$ & $\mathbf{B}_{\mathbf{2}}$ & $\begin{array}{l}\text { NaCl } \\
\text { concentrat } \\
\text { ion results } \\
\text { analysis } \\
(\boldsymbol{\%})\end{array}$ & $\begin{array}{l}\text { Calculation } \\
\text { results of } \\
\mathbf{N a C l} \\
\text { concentration } \\
(\boldsymbol{\%})(\mathbf{Y})\end{array}$ \\
\hline 0.00 & -1.42 & 84.58 & 87.25 \\
1.00 & -1.00 & 87.46 & 90.78 \\
1.00 & 1.00 & 86.31 & 92.78 \\
0.00 & 0.00 & 93.12 & 93.42 \\
-1.00 & 1.00 & 92.96 & 97.48 \\
0.00 & 0.00 & 92.38 & 93.41 \\
-1.00 & -1.00 & 86.37 & 87.48 \\
-1.42 & 0.00 & 85.22 & 93.22 \\
0.00 & 1.42 & 97.45 & 95.74 \\
1.42 & 0.00 & 87.16 & 92.22 \\
\hline
\end{tabular}


From Fig. 4 it can be concluded that both data are approximately being identical with small deviation. Therefore, the model can be used in the process of increasing levels of $\mathrm{NaCl}$. Fig. 5 indicates that for the value of variable $B_{1}=0.0$ and $B_{2}=1.4$, the concentration of $\mathrm{NaCl}$ salt is about $97 \%$. This value is below standard $98.5 \%$ and this is may be due to the lack of $\mathrm{Na}$ stearate added.

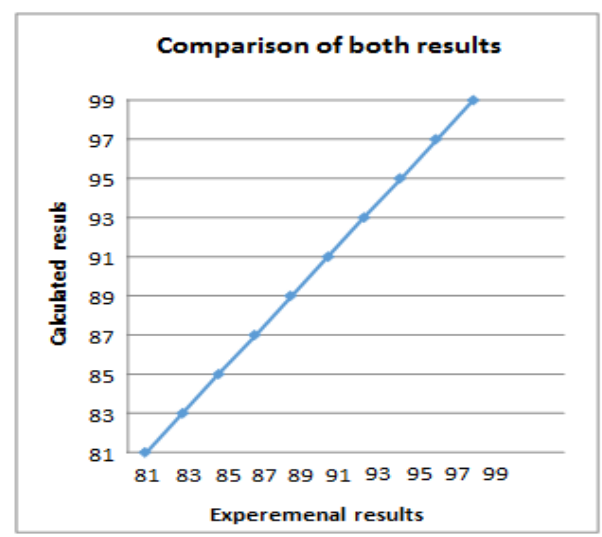

Fig. 4. Comparison between calculated and experimental results on production of $\mathrm{NaCl}$.

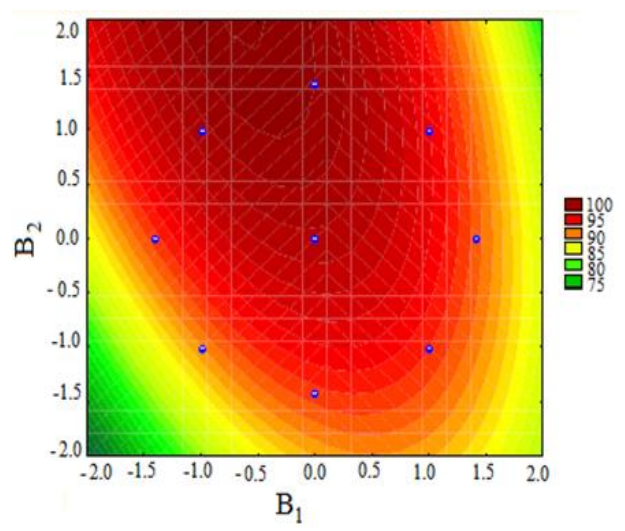

Fig. 5. Two-dimensional graph of production of $\mathrm{NaCl}$ salt.

\section{CONCLUSIONS}

From the results obtained, it can be concluded that according to the mathematical model Eq. (3) for the reduction average in $\mathrm{Ca}^{+2}$ and $\mathrm{Mg}^{+2}$, the maximum value of conversion average is $95 \%$ on the value of $B_{1}=-0.71$ at a temperature of $83^{\circ} \mathrm{C}$ and for variable $B_{2}=2.7$ the concentration of sodium stearate is about $15 \%$.

According to the mathematical model Eq. (4), the concentration of $\mathrm{NaCl}$ is about $95 \%$ and for the variable $B_{1}=-0.7$ or a temperature of $81{ }^{\circ} \mathrm{C}$ and variable $B_{2}=2.25$ the concentration of sodium stearate is about $13.11 \%$. both data are approximately identical with small deviation. Therefore, according to process used in this research, we can conclude that the mathematical models Equations. for mean reduction in $\mathrm{Ca}^{+2}$ and $\mathrm{Mg}^{+2}$ can be successfully used in the process of increasing levels of $\mathrm{NaCl}$ salt concentration.

\section{REFERENCES}

[1] Golbas B. Role of salt in the formation of anatolian culture. Journal of Life Sciences 2012; 1 (1): 45-54.
[2] Cunningham S. Wicca: a guide for solitary practitioner. Worldwide; 1989.

[3] Elvers B. Ullmann's Encyclopedia of Industrial Chemistry 1991; A24: 319

[4] Pieters AJEB, et al. Experiment station work: Bread and the Principles of Bread Making. USA: 1899: 2830.

[5] McNeil DG. In raising the world's I.Q. secret's in the salt. The New York Times: 2006.

[6] Discussions of the safety of sodium in table salt. Retrieved 7 July 2011.

[7] He, FJ, Li J. Effect of longer term modest salt reduction on blood pressure: Cochrane systematic review and meta-analysis of trials. BMJ (Clinical research ed.); 2013: 346.

[8] Aburto NJ, Anna H. Effect of lower sodium intake on health: systematic review and meta-analyses. British Medical Journal 2013: 346 (f1326). 